
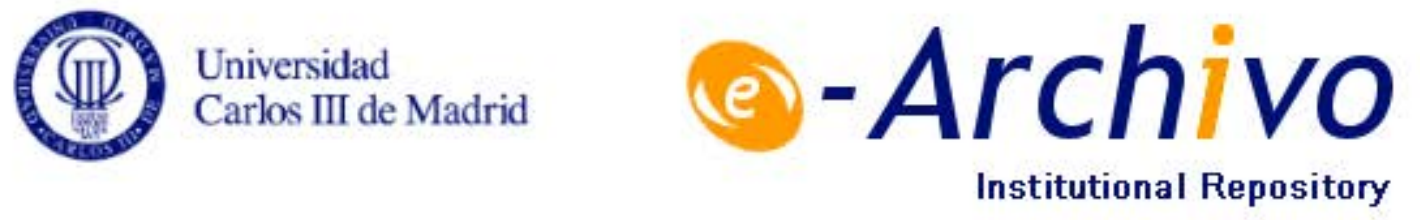

This is a postprint version of the following published document:

Melero Salvador, Alejandro. Censorship and the Construction of Homosexual Desire in Mario Camus's Muere una mujer (1965) En: Bulletin of Hispanic Studies, V. 94, N. 9 (2017), pp. 987-1000

(C) Liverpool University Press 


\title{
Censorship and the Construction of Homosexual Desire in Mario Camus's Muere una mujer (1965)
}

\author{
Alejandro Melero. Universidad Carlos III de Madrid
}

\begin{abstract}
The representation of homosexuality and homosexual desire in cinema was strictly banned under Franco's dictatorship. However, a limited number of filmmakers managed to portray homosexual characters in their films. The popular melodramas of the 1960 s were a good chance for these novel representations, and filmmakers of younger generations explored new cinematic discourses on sexuality. This article studies Mario Camus's Muere una mujer (1965), an important work in the construction of the film discourses on sexual minorities that would flourish during the transition to democracy. This film can therefore be considered a valuable source for understanding future homosexual narratives. Despite the strict demands of the 'Junta Nacional de Censura' - the Board of Censors Camus managed to include homosexual characters who, very xceptionally, expressed their desires. The study of the censorship files, which can be found in the Archivo de Alcalá (Madrid), contribute to the analysis of the complex processes of narration and deletion of homosexual desire.
\end{abstract}

\section{Resumen}

La representación de la homosexualidad y del deseo homosexual en el cine estaba estrictamente prohibida durante el Franquismo. Sin embargo, un pequeño grupo de cineastas se las ingeniaron para mostrar personajes homosexuales en sus películas. Los melodramas populares de los años sesenta suponían una buena oportunidad para este tipo de representaciones, y cineastas de generaciones más jóvenes exploraron estos nuevos discursos en el cine. Este artículo estudia Muere una mujer (1965), de Mario Camus. Se trata de un trabajo importante en la construcción de discursos cinematográficos en torno a las minorías sexuales, que proliferarían en la transición a la democracia. Esta película se puede considerar, por lo tanto, una fuente muy valiosa para el estudio de las futuras narrativas homosexuales. A pesar de las estrictas exigencias de la censura, Camus consiguió incluir personajes homosexuales que, excepcionalmente, expresaron sus deseos. El estudio de los expedientes de censura, que se encuentran en el Archivo de Alcalá (Madrid) contribuye al análisis de los complejos procesos de narración y eliminación del deseo homosexual 
Although the representation of homosexuality and homosexual desire in cinema was strictly banned under Franco's dictatorship, a limited number of filmmakers managed to portray homosexual characters in their films. 1 The popular melodramas of the 1960s provided a good opportunity for these novel representations as filmmakers of younger generations explored new cinematic discourses on sexuality.

This paper studies Mario Camus's Muere una mujer (1965) as a landmark work in the creation of film discourses on sexual minorities that would go on to flourish a few years afterwards, during the transition to democracy. This film can therefore be considered a valuable source for understanding the impending homosexual narratives of the 1970s. I further study how, despite the strict demands of the Board of Censors, Camus managed to include a homosexual character who very exceptionally expresses his sexual desires. There are three main considerations that I want to analyse: first, I use D. A. Miller's theories on the binomial connotation-denotation and its importance in the production of homosexual narratives; second, I question the much-discussed presentation of Franco's censorship as 'arbitrary' (Gubern 1975: 50); and, finally, I use the pseudo-scientific literature of Francoism in order to understand the specificities of the Spanish obsession with the detection and uncovering of homosexuality and homosexual behaviour. In order to do this, special attention will be paid to the study of the censorship files, which can be found in Archivo de Alcalá (Madrid). The archives ultimately contribute to my analysis of the complex processes of and tensions inherent to the narration and deletion of homosexual desire.

\section{Homosexuality and Spanish cinema in the 1960s}

The study of the representation of homosexuality in the Spanish film narratives of Francoism is still insufficient to explain the complexities of the construction of homosexual desire. Academics and film historians have taken for granted the idea that homosexuality was forbidden in Spanish cinema, and as a result these representations have been considered to be very few. Thus, the film Diferente/ Different (Luis María Delgado, 1962) has traditionally been studied as a precious flower in the vast desert of Spanish LGBT cinema. The works of Paul Julian Smith (1992) and Alberto Mira (2008) have been pioneers in the study of the relationship between cinema, censorship and homosexual desire, yet they have obliquely reinforced the idea that such narratives were exceptional and rare. By working on the assumption that the cinema of this period ignored homosexuals, research has overlooked a time of great relevance in Spanish cinematography and culture. The so-called 'Desarrollismo' (which began with the 1959 Stabilization Plan and ended in 1973, after Carrero Blanco's death) constituted a neo-capitalist liberalization of the economy with the 
jettisoning of the economic principles supported by National Socialism. The arrival of tourism and the dictatorship's rapprochements with the European Community are usually considered to be the key events of this time. Minister Manuel Fraga became the most visible figurehead in the new (officially more liberal) politics, while filmmakers (soon to be known as members of the Nuevo Cine Español) experimented with new cinematic possibilities.

1 The research leading to this article has been funded by 'Cine y televisión en España 19861995: modernidad y emergencia de la cultura global', CSO2016-78354-P, Ministerio de Economía y Competitividad. Plan Nacional I+D 2009.

The fact is that not only is it possible to find representations of homosexuals in the cinema of this period but a careful viewing of many titles of the time also shows their presence in a wide variety of genres. Comedy, a genre in which there would be a proliferation of characters in the role of 'mariquitas', continually highlighted homosexuality, although homosexuals were always in secondary roles (see Melero 2010: 127-80). In popular comedies such as / Los gemelos de Tejas/Twins from Texas (Steno, 1962), La boda era a las doce (Julio Salvador, 1964) and Algunas lecciones de amor (José María Zabalza, 1966), we can find characters who are clearly coded as homosexual. I have noted elsewhere that even in a genre as unthinkably homosexual as the then extremely popular spaghetti western, interesting representations of homosexual characters can be found. For instance, the two cowboys in the Spanish/ Italian co-production Trampa para un forajido/ Ringo's Big Night (Mario Maffei, 1967) end up developing a suspicious bond, which leads them to opt for a solitary life on the prairies with just each other for company, shunning the option of going lawful proposed to them by the federals. In the same film, there is even one scene in prison full of homosexual innuendo: when one of the cowboys asks his friend to take his trousers off, the other responds with great surprise, only to learn that the request is simply a means of pulling down the iron grating to escape. The list of examples is very long and could include, among many others, La tonta del bote (Juan de Orduña, 1970), La dinamita está servida (Fernando Merino, 1968), La chica del trébol (Sergio Grieco, 1963), Cuarenta grados a la sombra (Mariano Ozores, 1967), Terror in the Crypt/ La maldición de los Karnstein (Camillo Mastrocinque, 1964) and La casa de las mil muñecas / The House of One Thousand Dolls (Jeremy Summers, 1967), to name but a few. Representations of homosexuality in the Spanish cinema of the Franco era was, to be sure, very problematic, and filmmakers attempting to portray sexual minorities faced several restrictions, as this paper will study. However, this must not make us believe that such representations were impossible or even few. In any case, and in the hope that future research develops this corpus of films 
and gives them their due analysis, the following paragraphs will focus on melodrama and takes the film Muere una mujer as its main case of study. 2

2 In the last few years, the number of hispanists studying the relationship between censorship, homosexuality and literature under Franco has increased and they have successfully produced very relevant work. For more on this, see Linder 2004.

\section{Censorship and the construction of homosexual desire}

Muere una mujer is a fine example of the popular melodramas of the time. Although the 1960s are remembered for their 'musicales con niño' and spaghetti westerns, a look at the box office and film magazines of the time reveals that melodrama was then one of the most popular genres. 3 The appeal of these melodramas for filmmakers of younger generations can be seen in the fact that the script of Muere una mujer was written by Carlos Saura just a few years before he became considered Spain's most important auteur.4 Muere una mujer was Camus's third film, right after his success with Young Sánchez (1964), for which he received a Special Mention in the Mar de Plata Festival of 1964. He had become Spain's most promising young director, and the popular success of Muere una mujer, with over 350,000 spectators, secured him work in future popular films starring Sara Montiel and by Raphael. Muere una mujer tells the story of Javier (Alberto Closas), a womanizer whose wife dies under mysterious circumstances: on a tranquil day, when they are on the beach with their little child, the wife suffers a heart attack and falls down a cliff. Later, he discovers that she suffered a heart attack.

Before making this discovery, he finds a corpse in the trunk of their car and starts his own investigation. He uncovers the identity of the dead person: Víctor Andrade, a young and attractive man who was the protégé of Juan de la Peña, Javier's neighbour. As the investigation proceeds, Javier learns that Juan de la Peña and Víctor had been lovers and that when Víctor decided to abandon his older benefactor, de la Peña refused to accept the rejection and killed him.

Homosexuality is therefore crucial to the development of the plot and the construction of two of the main characters of the story. The following section will study the process and development of the construction of homosexual characters and homosexual desire in this film's narrative. In order to do so, I study the original script of the film, which can be found in the Biblioteca Nacional (Madrid), and the files of the Censorhip Board (in the Archivo de Alcalá). I will analyse how the presentation of homosexuality by the filmmakers was highly determined by the interference of censorship and how, nevertheless, a discourse 
of homosexuality remained in the final film text. Before doing so, I will explore the fraught relationships between censorship and homosexual narratives in cinema.

3 Not to mention that most of those musical films could easily be classified under the category of melodrama, too. For instance, most of Joselito's films tell the story of an orphan child who encounters his lost mother, an expressly melodramatic trope in cinema. 4 Future prominent writers of democratic Spain also started their careers writing these melodramas. For instance, Antonio Gala wrote the script for Pepa Doncel (Luis Lucia, 1969), starring Aurora Bautista. This film updated Jacinto Benavente's popular play and continued thus a tradition of homosexual playwrights (in Spain, Lorca; other names are Tennessee Williams, William Inge, Noël Coward, Tony Kushner...) writing about passionate and unhappy women who suffer from unrequited love.

Queer film studies has long been concerned with the place of censorship in the construction of film narratives that deal with homosexuality. Since the early years of cinema, both official and non-official codes of censorship determined the representation of sexual minorities onscreen, as Vito Russo expertly proved in his seminal book The Celluloid Closet (1987). Russo detailed how different legislations influenced the portrayal of omosexuality in films of all times and countries, including landmarks of gay cinema such as Advise and Consent (Preminger, 1962, USA) and Victim (Dearden, 1961, UK). Russo's research included files from different boards of censorship, and his conclusions are still used by many film historians and scholars. For instance, Charles Kaiser refers to him in his study of American gay urban life in the 1960s (1997: 155). Moreover, Russo's legacy for film scholars goes beyond Queer Studies, as can be seen from the fact that his ideas on censorship have been taken up by people such as Christa Albrecht-Crane and Dennis Ray Cutchins, who refer to Russo in order to study the importance of censorship in film adaptation (2010:37). When it comes to the study of censorship and homosexuality in Spanish cinema, it seems that there is still much work to be done. Obligatory prior censorship of all forms of entertainment, including scripts, had been instituted right after Franco's victory, and censorship was not abolished until 1977. Román Gubern, one of the pioneers in the study of censorship, has often remarked how 'the existence of some form of state censorship $[\ldots]$ has been a major factor affecting what could or could not be produced - other factors being the availability of finance (tied up with censorship) and questions of audience taste' (Gubern 1981: 391; my translation). Alberto Gil's book La censura cinematográfica en España (2009) includes one chapter on homosexuality, but he focuses on how American, French and Italian films were censored in Spain, and nothing is said about Spanish cinema. Nevertheless, his research gives an overview of how the Board of Censors operated when they found an explicit or potential representation of homosexuality. One example that Gil analyses is Voulez- 
vous danser avec moi?/ Come Dance with Me/ ¿Quiere usted bailar conmigo? (Michel Boisrond, 1959), starring Brigitte Bardot. Gil quotes one of the censors, who wrote: 'Es inadmissible presentar la homosexualidad masculina bajo color de diversión, sin ningún juicio de valor sobre el drama que ella representa. Esta película tiene que ser rechazada para todos los públicos' (Gil 2009: 55). These lines are very clear about the fact that a non-dramatic representation of homosexuality was not tolerated.

At the same time they suggest that, had that film presented a perspective in which homosexual behaviour was seen as something dramatic (and possibly condemned), the reports would have been different.

The process of censorship in Spanish cinema of the Franco era varies depending on the historical moment and there are substantial changes between the rules and procedures of the post-war years and those of the 1970s. In February 1963, García Escudero, Director General of Film and Theatre, instituted a new Censorship Code which explicitly banned 'apologies of suicide, euthanasia, revenge crimes and duels, divorce, adultery, illicit sexual relations, prostitution, abortion, or contraception; the representation of sexual perversions, drug addiction, alcoholism, or overtly explicit crimes' (Gubern et al. 2012: 398). This particular Censorship Code clearly affected the production of Muere una mujer. At that time, there were normally five different steps in the process of censorship: first, the script was submitted to the Board of Censors, whose members could approve it, reject it, or approve it only after some changes had been made (this third option was taken most often). This first step could therefore take as long as the rewritings would demand, and the production company could send a letter explaining the changes or even try to calm the censors down. These letters are invaluable testimonies for scholars interested in the processes of censorship, as they are sometimes kept in the files that we can find today. Once the script had been approved, the second step consisted of inspections that took place during the shooting of the film; unfortunately, no records of these inspections have survived.5

The third step was a private screening of the film, as presented by the production company. The Board of Censors would again approve it, reject it, or approve it pending certain revisions. They would specify those changes and, after another screening, the film would be awarded its distribution licence.

This dense labyrinth of bureaucracy is at once the scholar's best friend and enemy. On the one hand, Francoism's obsession with bureaucracy provides access to precious information; but on the other hand the sometimes chaotic situation of the files can impede the success of the research. It is most often the case that documents are kept that relate to just one of the three steps outlined above. The case of La luz del fin del mundo/ The Light at the Edge of the World (Kevin 
Billington, 1971), is a valuable one, as all the documents from all the steps have been kept and they clearly show how the original homosexual relationship of the two main characters was altered after the interference of the censors, until its absolute disappearance.

In the case of Muere una mujer, we have the documents of the script censorship(step 1), the reply of the production company, and the postscreening report (step 3). Thus, the lines that aimed at removing all references to homosexuality after reading the script include the indications that 'the following lines must be deleted'. They are part of the monologue of one character who is being interviewed by Javier, as part of his investigation:

Secuencia 40, páginas 58 y 59:

No podía vivir. Eso me dijo. No puedo seguir viviendo así. El viejo estaba en Madrid, y le llamaba cada dos horas. Cuando no estaba, se enfurecía. Quería controlarlo, tenerlo dominado. Por eso discutían y se amenazaban. Aquel día [yo] había estado en su casa. El viejo había llamado varias veces y Víctor a pesar de que estaba junto al teléfono no había querido ontestarle. Estaba dispuesto a dejarle. A establecerse por su cuenta. 6

5 In my research I have studied the files of over 300 films made between 1933 and 1976 and such reports are not to be found.

6 This, and all the subsequent extracts about Muere una mujer are taken from the Documentos de censura, Folders AGA 36/04155 and AGA 36/04105.

Later, another indication demanded that the following explicit reference was to be removed: 'Víctor estaba muy orgulloso porque finalmente le había dejado'.

The verdict ends with a letter, dated 20 May 1964, in which the members of the Board of Censors explicitly manifest their desire to delete all references to homosexuality, while expressing judgements on the quality of the work: Típico guión policiaco. No muy bueno en ese aspecto concreto, y sostenido, como eje de la trama, en la presentación de una perversión sexual, y en una equívoca actitud por parte del protagonista. Creo que debe ser prohibido [emphasis in original]. Al guión cabe hacerle las oportunas modificaciones, evitando la homosexualidad señalada sin rebozo.

The production company, Moncayo Films, answered with a letter in which they apologized for the script that they had presented. The very first paragraph deals with the question of homosexuality:

Muy señores míos,

habiendo fallado en contra del guión de Muere una mujer, por las características homosexuales que se dan en dos de sus personajes faltando así al artículo 9 del Código de Censura Vigente, advertimos que este carácter pertenecía a una versión anterior del guión y que en esta hemos intentado desecharlo en absoluto. 
Later, the letter insists:

hacemos las oportunas rectificaciones intentando dejar limpio este aspecto de la cuestión, advirtiendo que no es nuestra idea el considerar fundamental estas relaciones ni que siquiera de manera indirecta se pueda pensar que tiene este matiz. (emphasis mine)

The Board of Censors replied to this second version of the script with satisfaction, and the head of that commission, Sebastián de la Torre, stated: Creo que las modificaciones que se presentan descargan suficientemente la duda en cuanto al homosexualismo de Víctor de la Peña [...]. En caso de que la realización cargara la mano en el homosexualismo podría ser motivo de objeción fundamental.

The whole original script had flirted with the idea that Juan and Víctor were lovers, but it is only in the final confession of the murderer that spectators are (or, rather, were in the original script) informed of the veracity of that hypothesis. Predictably, the censors were unhappy about the explicitness of the confession, and demanded that those lines were removed. Before the homosexual killer's confession, other lines had explicitly mentioned homosexuality; during his investigation, Javier meets Víctor's former girlfriend, who, at one point, says that she knew that Juan and Víctor were 'novios'. That entire conversation had to be removed upon the censors' indications. The lines that the censors asked to be removed are these:

No podía vivir. Eso me dijo. El viejo estaba en Madrid aprovechándose de un proyecto que pertenecía enteramente a Víctor. Ese mismo día le llamo y Víctor estaba muy orgulloso porque rompió definitivamente con él.

Acababa de aceptar el ir de ambientador en una película que se va a rodar aquí. El viejo se enfadó y le dijo que esperara, que tenía que hablar con él. Estaba dispuesto a dejarle, a establecerse por su cuenta. Cuando estaba un poco bebido le dijo que era un auténtico negro, un esclavo, y que no le importaba volver de nuevo a empezar, como antes, cuando éramos novios. These lines, which were finally removed, reinforced the idea that Victor's and Juan's relationship was one of abuse and power. More importantly, they suggested Juan's return to heterosexuality ('no le importaba volver de nuevo a empezar, como antes, cuando éramos novios'), an idea which paradoxically reinforces the characters' homosexuality. The following section studies how these paradoxes are precisely the base for the construction of homosexuality in the narratives of classic cinema.

\section{Homosexuality and connotation}

The intervention of censorship clearly determined the final text of Muere una mujer, but in the study of the representation of homosexual desire, other relevant questions arise, including those issues of spectatorship in the film. Queer film theory has long debated the codification of homosexual 
desire onscreen and, in fact, D. A. Miller has developed a whole theory around what he calls the 'binomial connotation/ denotation'. Miller takes Hitchcock's Rope (1948) as his case study, exploring how the narrative of the film depends not so much on the homosexuality of the murderers but on the possibility that the murderers may be (or may not be) homosexuals. Miller is bewildered by the fact that the (in)famous homosexuality of the killers in the film is 'not in the story at all' (Miller 1991: 121). The spectator is instead invited to participate in a game of decoding messages that might display or disclose the sexuality of the characters. The 'transgressive fascination of homosexuality' (1991: 122) is substituted by complex cinematic techniques (camera work, mise en scène) that help (or, rather, incite) the spectator to consider homosexuality while it also follows the 'cultural surround of legal, social, psychic, and aesthetic practices (the last one including those of spectatorship) that tolerate homosexuality only on condition that it be kept out of sight' (123). Miller points out how the most problematic of all the representations of homosexuality is that of "the fantasmatic prospect of "gay male sex" (133). Homosexuality offers a unique subject matter which appertains to "the shadow kingdom of connotation, where insinuations could be at once developed and denied, where $[. .$.$] one couldn't be sure whether homosexuality was being meant at$ all, but on the chance it was, one also learned, along with the codes that might be conveying it, the silence [it was] necessary to keep about their deployment' (125).

The submission of homosexuality to connotation implied that every discourse around homosexuality could be "haunted by the phantasm of the thing itself, not just in the form of the name, but also, more basically, as what the name conjures up: the spectacle of gay sex' (130). And this is where the suspense of Rope is: the film excites a desire to see (sex) while it also inspires a fear of seeing (131). Because gay sex is 'phobogenic' (134), spectators will be moved by the presence of it while filmmakers can make use of it as a narrative device that creates suspense (as Hitchcock did), scandalizes, or transgresses norms.

D. A. Miller's theories are ideal for exploring how Franco's censorship worked to frustrate the presentation of homosexual desire in Muere una mujer. In Rope, spectators are invited to fantasize with the potential homosexual relationship of the characters: are they gay at all? Do they share the same room, as the mise en scène seems to suggest? Do their relatives know about their relationship? Muere una mujer presents pretty much the same game: we see Víctor and Juan relaxing in a swimming pool, and a point of view shot shows Juan looking at his lover's semi-naked body, which is followed by the camera as if it were Juan's gaze. Spectators are also invited to their house and, as in Rope, we can presume 
that the only door in the lounge hides the only bedroom. When we see Juan and Víctor leave their house together, we may ask ourselves the same questions as Miller did upon viewing Rope.

We can conclude that Miller's binomial connotation-denotation applies to the creation of homosexuality in Muere una mujer, but the study of censorship problematizes Miller's strategy. The files presented earlier reveal how, in order to get the approval, both the production company and the scriptwriters aimed at removing not only the representation of homosexual desire but also the mere possibility that such a connotation might exist. When the producers wrote in their response letter that 'no es nuestra idea el considerar fundamental estas relaciones ni que siquiera de manera indirecta se pueda pensar que tiene este matiz' (my emphasis), they were making sure that Hitchcock's strategy, as studied by Miller, was not possible in Spanish cinema. Sebastián de la Torre, the head of censors, was therefore very right to be happy about the elimination of what he called doubt ('duda'). In a very Hitchcockian twist, the shadow of the doubt of homosexuality had disappeared (according to the censors), even if de la Torre insisted that attention should be paid during the shooting.

\section{Censorship and arbitrariness}

The next question I want to look at is that of the much-discussed arbitrariness of the Francoist censorship system. According to Román Gubern, 'censorship was arbitrary' (1981: 397; my translation), and this 'arbitrariness gave rise to paradoxical situations'. As an example, he notices how the censors 'failed to pick up the homosexual choreographic fantasies of Luis María Delgado's Diferente'.

The question of arbitrariness has been noticed by most of the authors who have studied the censorship of Francoism. Thus, Alberto Gil's book, $L a$ censura cinematográfica en España, starts with the following anecdote which, according to him, describes the main characteristics of Franco's censorship:

We know very little about Franco's weaknesses and personal tastes, but we do know that he was a cinephile. We also know that, while in the darkness of his private cinema, he used to cough a little to show his disapproval, at the same time that he paved the ground for one of the most firm, wide and arbitrary censorship systems in the twentieth century. (Alberto Gil 2009: 9; my translation)

I want to argue that in the case of the representation of homosexual desire and characters 'arbitrariness' is not the word that best describes the censors' criteria (or lack of criteria, if we understand 'arbitrariness' precisely as the absence of consistent rules). On the contrary, the alarm went off very quickly when the censors perceived or imagined the potential presence of homosexuality. As seen above, Muere una mujer is a good case 
to illustrate this point. Not only is homosexuality felt as a dangerous element in the original script, but it also eclipses all or most of the other uncomfortable aspects of the film. Thus, the question of adultery, which was normally strictly regulated (see, for instance, Gil's chapter on 'El adulterio' (2009: 133-55), which includes the analysis of films of the same year as Muere una mujer), does not seem to concern the censors who read the script by Camus and Saura (1964); accordingly, there is no reference to adultery in the files that remain, even though it is a very obvious aspect of the film. The same can be said about other questions that appear in Muere una mujer, such as the representation of the police as inefficient (according to Gil (2009: 236; my translation)), 'the police and their actions could never be questioned on cinema, not even as a joke and, naturally, any display of rebellion against the authorities was forbidden', or the idea of suicide, which are also topics that are part of the film. A hierarchy of unwelcome representations can thus be established and, in the case of Muere una mujer, homosexuality is at the top of the pyramid, to the extent that all other forbidden topics are ignored.

It can therefore be argued that the existence of this hierarchy challenges the notion of the arbitrariness of censorship. This point can be reinforced with the study of other films and scripts in which, despite the fact that there is no presence of homosexuality at all, the censors were so concerned with the possibility of its appearance that they went so far as to warn the writers. This happened to the script of Las amazonas/ The Amazons (Terence Young, 1973), an adventure film destined for 'people of all ages'. One censor noticed: 'these women who live alone do not seem to mingle with men. The innocent spectator may wonder about these solitary women's lives. All references to lesbianism will have to be banned if this film wants to see the light' (Las amazonas (El triunfo de Teseo), 1973. Folder AGA 36/05375).

This censor's obsession with homosexuality made him so alert that he saw homosexuality only in its potential representation. Such pre-emptive censorship raises an interesting question about the frustrations and the limits of the powers of censorship, as homosexuality is potentially present in all contexts and situations (and not necessarily more prevalent in an island of warrior women, as we see in the script of Las amazonas). An even more extreme case of this obsession with homosexuality (which, I want to argue, I have not found applicable to other topics and therefore confirms that homosexuality was at the top of the undesirable subjects in the hierarchy of censorship) is that of the filmmaker Jesús Franco. One of the censors of his film El diablo que vino de Akasawa/ The Devil Came from Akasava (1971) stated: 'knowing this director and the fame that precedes him, I would not be surprised if lesbianism and homosexuality would be 
displayed in the final cut' (El diablo vino de Akasawa, 1970. Folder AGA 36/05345 and AGA 36/04393). Censors were over-cautious on this aspect, and some of them perceived homosexual relations where it is very difficult to find them. Padre Benito and Pío García Escudero are among the censors whose reports are full of references to condemnations of homosexuality. The list of films and files in which the relevance of the arbitrariness of censorship is denied is long, and Muere una mujer is a clear example that may potentially contribute to future studies of the complex relationship between homosexuality and censorship.

\section{Uncovering homosexuality}

There is one very important aspect to take into account in order to understand the presence of homosexual characters in Muere una mujer and the processes by which censorship tried to remove them. The censorship reports studied above show how the censors struggled to identify characters as homosexuals. When the censors wrote about 'an ambiguous attitude of the main character' or the 'homosexual characteristics of two characters', they were looking for traits that could prove the homosexuality of people. Something very similar happened to the police and judges who prosecuted real homosexuals at that time, often with the assistance of doctors. Medical and legal literature on how to uncover homosexuality flourished in Spain during the late 1950s and early 1960s, as Arturo Arnalte has remarked (2003: 81-114). In the following paragraphs, I will look at the theories developed by doctor Pérez Argilés, who was then known as the biggest expert on this field and who influenced the jurists who would subsequently write the notorious Ley de Peligrosidad Social. This set of laws was used to prosecute homosexuals between 1970 and 1979, replacing the Ley de Vagos y Maleantes. For Pérez Argilés, the most dangerous characteristic of homosexuality (and the reason why it should be penalized) was its contagious capacity. His ideas on 'sexual inversion' were put forth in his Discurso sobre la homosexualidad (1955), which would be quoted by jurists and judges as the empirical justification for their decisions. Antonio Sabater, one of the four men who wrote the Social Danger Act, quotes Pérez Argilés as his main reference for the law (Sabater 1962: 183). Pérez Argilés seems to have become the most prominent scientist of homosexuality in Francoism and as such is cited in every essay, medical or judicial, that deals with the topic. As a doctor, he must have been aware of the relevance of his texts and most of them were orientated towards the formulation of a legal status for homosexuals and the ways to discern them. His Discurso, a medical text, addresses jurists and urges them to free society from 'invertidos' and from 'el riesgo gravísimo representado por el hecho de dejar en libertad de actuación a los invertidos, por el peligro de corrupción de una juventud predispuesta, antes de la plena formación de la 
libertad' (1955: 41). Pérez Argilés presented his discoveries in the field, starting with an aspect that would be crucial to policemen and judges: how to uncover a homosexual. According to his studies, there are several features that can expose homosexual men from their secrecy; features which include physical prescriptions, such as 'Tono de voz y ademanes [...]. La relación entre el cinturón torácico y el pelviano [pues] En el varón debe predominar la anchura del torácico sobre el pelviano [...] Presencia de un fuerte apéndice xifoides' (1955: 38). According to the Discurso, a man whose thorax is thinner than his pelvis is a suspect of homosexuality. Pérez Arguilés does not ignore popular wisdom and includes in this list the inability of homosexual men to join both elbows when the arms are rigid (1955: 38), a theory taken from Spanish folklore that few people support nowadays. This constitutes what Pérez Argilés calls the morphological study, the first one to be applied due to its quick and easy performance. Should this not reveal a homosexual, Pérez Argilés suggests genetic and endocrinal studies, warning not to use hormones (as medical tradition dictated in Spain) since it was counterproductive and awakened the patient's libido (1955: 41).

Besides detecting homosexuality, Pérez Arguilés's school is also interested in discovering its causes. Although he admits to some limitations here, due to the novelty of such studies, and trusts future scientists to develop the research, some conclusions can be reached. Thus, he proves that too much masturbation does not lead to homosexuality (Pérez Arguilés 1955: 43). Other myths are also proven to be false, such as the inability of homosexual men to copulate with women (1955: 43). One of the reasons leading to homosexuality is what he calls self-erotic narcissistic attraction mixed with the inability (or 'ceguera estúpida') to appreciate the beauty of women (4647). Whatever the causes of deviant sexuality, he concludes, its cure will be reached by means of chastity, the only real technique able to channel their deviant behaviour: 'al invertido hay que encaminarlo por la castidad, que debe ser su ideal, más bien que la sensualidad normal'. This task is easier than it might seem because homosexuals are very sensitive people who have traditionally been used to channelling their passions into artistic and religious sublimation: 'el homosexual, por el camino de la castidad, puede alcanzar las más elevadas cumbres de la santidad [...]. El homosexual debe ser ayudado para el logro de tal sublimación, y una vez alcanzada, ya no precisa los sentimientos humanitarios y caritativos de sus semejantes para merecer la consideración y el respeto de sus conciudadanos' (48-49).

The inanity of Pérez Argilés' theories is relevant to the study of cinematic representations of homosexuality for several reasons. First, these theories locate the film in its historical context. Muere una mujer is a film about homosexuality, made when homosexuality was strictly banned and 
prosecuted. More importantly, Pérez Argilés' texts reveal in very explicit ways the mechanisms for unveiling homosexuality, and the absurdity of such task. And finding homosexuals was, after all, what Franco's censors were doing. When we read in the files that the characters present 'an ambiguous attitude' (as discussed above), we are in fact witnessing how the censors perceived the script. They feared that those characters might be homosexuals and, therefore, banned the film. The same thing happens later in the correspondence between the production company and the censors, when they discuss how to 'sufficiently unload the doubt about Víctor's and de la Peña's homosexualism'. Their prescriptions (such as 'the following lines must be deleted [from the script]') do nothing but locate the features that reveal the characters as homosexuals and then remove them, exactly in the same way that Pérez Arguilés was teaching judges and policemen how to remove homosexual people (and, sadly, not fictional characters) from society. These words suggest that (as Pérez Arguilés believed) there were features that could identify people as homosexuals, and that such identification was the duty of both the censors and those in political power. When the censors revised scripts and films looking for traces of homosexuality, they were doing nothing but applying Pérez Argilés' theories; Víctor and Juan de la Peña's sexuality could not be seen onscreen because of 'the high risk implied in [his] freedom, as [he] tended to corrupt the youths, as they are unsure before they are fully formed as adults', to use Pérez Argilés' vocabulary.

As Víctor's former girlfriend explains in the censored script, 'the old man was taking advantage of Víctor', who wanted to return to his heterosexual life (or so she thought). The homosexual narratives of films such as Muere una mujer can therefore be seen as reflections of the historical and cultural context of the time, which was extremely hostile towards sexual difference. However, one more interesting paradox arises here, for, while following Pérez Argilés' theories, the censors were making sure that debates about homosexuality were not popularized on film, even to condemn it. By reducing the story of Juan and Víctors (and deleting relevant fragments such as the testimony of Juan's girlfriend), the narrative of the abusive benefactor was weakened, no matter how well it agreed with Franco's official homophobia. It was actually anti-homosexual censorship which silenced a ruthless portrayal of a homosexual man. The results of the complex mechanisms of censorship may not necessarily be arbitrary, but they were uncontrollable. 


\section{Works cited}

Primary sources

Documentos de censura de:

Muere una mujer, 1963. Folders AGA 36/04155 and AGA 36/04105.

Archivo General de la Administración, Alcalá de Henares, Spain.

Las amazonas (El triunfo de Teseo), 1973. Folder AGA 36/05375. Archivo General de la Administración, Alcalá de Henares, Spain.

El diablo vino de Akasawa, 1970. Folder AGA 36/05345 and AGA 36/04393. Archivo General de la Administración, Alcalá de Henares, Spain.

\section{Secondary sources}

Albrecht-Crane, Christa, and Dennis Ray Cutchins, 2010, Adaptation Studies: New Approaches (Cranbury, NJ: AUP/ Madison, Teaneck, NJ: Fairleigh Dickinson University Press).

Arnalte, Arturo, 2003. Redada de violetas (Madrid: Esfera de los libros). Camus, Mario, y Carlos Saura, 1964. Muere una mujer. Guión cinematográfico (Título provisional)

Gil, Alberto, 2009. La censura cinematográfica en España (Barcelona: Ediciones B).

Gubern, Román, 1981. La censura. Función política y ordenamiento jurídico bajo el franquismo (1936-1975) (Barcelona: Editorial Península).

Gubern, Román, Josetxo Cerdán, Jo Labanyi, Steven Marsh, Tatjana Pavlovic and Nuria Triana Toribio, 2012. 'Censorship, Film Studios, and Production Companies', in A Companion to Spanish Cinema, ed. Jo Labanyi and Tatjana Pavlovic (London: Wiley-Blackwell), pp. 391-433.

Kaiser, Charles, 1997. 1968 in America (New York: Grove Press).

Linder, Daniel, 2004. 'The Censorship of Sex: A Study of Raymond Chandler's The Big Sleep inFranco's Spain', TTR: traduction, terminologie, rédaction, 17.1 (1st semester): 155-82. [DOI: 10.7202/011977ar] 
Melero, Alejandro, 2010. Placeres ocultos. Gays y lesbianas en el cine español de la Transición (Madrid: Notorious Ediciones).

Miller, D. A., 1991. 'Anal Rope', in Inside/Out. Lesbian Theories, Gay Theories, ed. Diana Fuss (London: Routledge), pp. 119-41.

Mira, Alberto, 2008. Miradas insumisas. Gays y lesbianas en el cine (Madrid, Egales).

Pérez Argilés, Valentín, 1955. Sesión inaugural del discurso académico celebrado el día 25 de enero de 1959 con un 'Discurso sobre la homosexualidad' (Zaragoza: La Academia).

Russo, Vito, 1987. The Celluloid Closet (New York: Harper \& Row). Sabater Tomás, Antonio, 1962. Gamberros, homosexuales, vagos y maleantes (Barcelona: Editorial Hispano-Europea).

Smith, Paul Julian, 1992. Laws of Desire: Questions of Homosexuality in Spanish Writing and Film 1960-1990 (Oxford: Clarendon Press).

\section{Filmography}

Advise and Consent. 1962, dir. Otto Preminger (Otto Preminger Films). Algunas lecciones de amor. 1966, dir. José María Zabalza (Uranzu Films). Cuarenta grados a la sombra. 1967, dir. Mariano Ozores (Cinehit; Productores Exhibidores Films - PEFSA).

Diferente/ Different. 1962, dir. Luis María Delgado (Águila Films). El diablo que vino de Akasawa/ The Devil Came from Akasava [original title, Der Teufel kam aus Akasawa]. 1971, dir. Jesús Franco (Central Cinema Company Film (CCC); Fénix Cooperativa Cinematográfica). La boda era a las doce. 1964, dir. Julio Salvador (Ucrania Film). La casa de las mil muñecas/ House of 1,000 Dolls. 1967, dir. Jeremy Summers (Constantin Film Produktion; Producciones Cinematográficas; Hispamer Films).

La chica del trébol. 1963, dir. Sergio Grieco (Mondial Cineproduzione; Procusa; Época Films).

La dinamita está servida. 1968, dir. Fernando Merino (Ágata Films). La luz del fin del mundo/ The Light at the Edge of the World. 1971, dir. Kevin Billington (Jet Films; The Bryna Company; Triumfilm).

La tonta del bote/ The Complete Idiot. 1970, dir. Juan de Orduña (Atlántida Films). 
Las amazonas/ The Amazons [original title, La guerriere dal seno nudo]. 1973, dir. Terence Young (Les Films de la Boétie; Monteluce Film; Films Montana).

Los gemelos de Tejas/ Twins from Texas [original title, I gemelli del

Texas]. 1962, dir. Steno (Cineproduzione Emo Bistolfi; Fénix Cooperativa Cinematográfica).

Muere una mujer/ A Woman Dies. 1965, dir. Mario Camus (Moncayo Films).

Pepa Doncel. 1969, dir. Luis Lucia (Moviola Films).

Rope. 1948, dir. Alfred Hitchcock (Warner Brothers; Transatlantic Pictures).

Terror in the Crypt/ La maldición de los Karnstein [original title, La cripta e l'incubo]. 1964, dir. Camillo Mastrocinque (E.I. Associates Producers; Hispamer Films; Alta Vista).

Trampa para un forajido/ Ringo's Big Night [original title, La grande notte de Ringo]. 1967, dir. Mario Maffei (European Incorporation; Fénix Cooperativa Cinematográfica).

Victim. 1961, dir. Basil Dearden (Allied Filmmakers).

Voulez-vous danser avec moi?/ Come Dance with Mel ¿Quiere Ud. bailar conmigo?. 1959, dir. Michel Boisrond (Francos Films; Vides Cinematográfica).

Young Sánchez. 1964, dir. Mario Camus (IFISA Producciones Cinematográficas). 